\title{
Deep Forestry
}

\section{Shaping the Longue Durée of the Forest in the Philippines ${ }^{1}$}

\author{
Greg Bankoff
}

The forest is a dynamic place, a complex ecosystem that has adapted over the longue durée to climatic and edaphic conditions. More than trees, the forest is also about plants, animals and the other agents that live in, use and consume the forest. Yet when it comes to writing forest history, the complexity of this system mainly vanishes: forest history becomes largely a narrative of human destruction of the forest over time. But there are other shapers of the forest. Climate and soil, to begin with, determine where and what types of species grow or predominate. Fire, while mainly anthropogenic (human-induced), is also autogenic (naturally induced) even in tropical forest. And then there are the living agents, starting with the white ants that prune away trees that are weak and consume the dead ones. They, too, have a close relationship with human behaviour in ways that decide which species are felled and for what purpose. Finally there is humanity, with all its changing needs and wants as well as its increasing desire for land to cultivate, largely at the expense of the forest. Over the centuries, these processes have shaped the forests of the Philippines in many and varied ways.

Finding the right balance between nature and humanity in the forest has not always been an easy matter to determine. On the one hand, ecologists view people as just one among a variety of factors that alter the environment (Christensen 1989:116). Historians, on the other hand, see the forest as largely 'synthetic' (R. Nash 1972:336). If the subsequent development of environmental history as a recognized sub-discipline has been partly driven by a desire to put the science back into history (Worster 1994:ix-xi), the emergence of historical ecology has been more of an attempt to examine 'history from the viewpoint of nature' (Whitney 1994:4). The result has been a profusion of new forest histories that do justice to both disciplines.

'Deep forestry' is an attempt to put the nature back into the study of Southeast Asian forest history and combines both a bio-centric (ecology-centred) and anthropocentric (human-centred) focus. It invokes a qualified comparison with the norms and values that underlie deep ecology. As defined by Arne Naess,

1 An extended version of this chapter first appeared in Environmental History 18, no. 3 (2013): $523-55^{6}$

(C) GREG BANKOFF, 2015 | DOI 10.1163/9789004288058_003

This is an open access chapter distributed under the terms of the Creative Commons Attribution- 
deep ecology includes among other things an awareness of the internal interrelatedness of ecosystem (Naess 1973:95-98). In particular, Aldo Leopold's exhortation (1979) to reject the primacy of human needs and instead 'think like a mountain' captured the new spirit of the time. Harking back to Leopold's injunction, deep forestry is an attempt 'to think more like a forest'. As historiography, it extends the web of relationships to include nonhuman factors. Its temporal reach, therefore, spans millennia rather than centuries. Exploring forest history from this perspective adds to both the knowledge of how the forest changed over time and the extent to which human actions contributed to those processes. Applying a deep forestry approach shows how the forests of the Philippines have been shaped as much by non-human factors as by human hands, though the balance has certainly shifted over time with human influence steadily growing. Climate, soil, fire and animals have left an imprint on the forest both through their own actions as well as through their influences on human agency.

\section{Climate and Soils}

The climate of the archipelago is controlled first of all by latitude and then by altitude. Lying between the equator and the Tropic of Cancer, the lowlands of the Philippines experience average temperatures in the mid to high twenties centigrade (Wernstedt and Spencer 1967:41). Rainfall is the most important climatic element as regards the characteristics of forest growth. Monsoonal or rain-bearing winds govern precipitation rates over the entire western side of the archipelago, the climate being marked by very distinct wet and dry seasons. Over the eastern half of the islands, rainfall is distributed throughout all the months of the year and there are no pronounced wet and dry seasons. These two different climatic regions roughly cut the Philippines in two (Wernstedt and Spencer 1967:58-62).

While there is little difference in the total precipitation between west and east, there is great variety in seasonal rainfall (Wernstedt and Spencer 1967:5357). In general, species requiring a large amount of moisture in the soil flourish in the eastern region. The best development of dipterocarps, therefore, occurs in the eastern and northern part of Negros and in other parts of the Visayas, on Mindanao, and along the east coast of Palawan. Species that flourish in fairly dry situations are to be found across the archipelago as there are areas of relatively low rainfall in both east and west. Moreover, at elevations over 900 metres, rain falls throughout the year making the climate suitable to trees demanding high atmospheric humidity. As a rule, though, certain species prosper in one or 


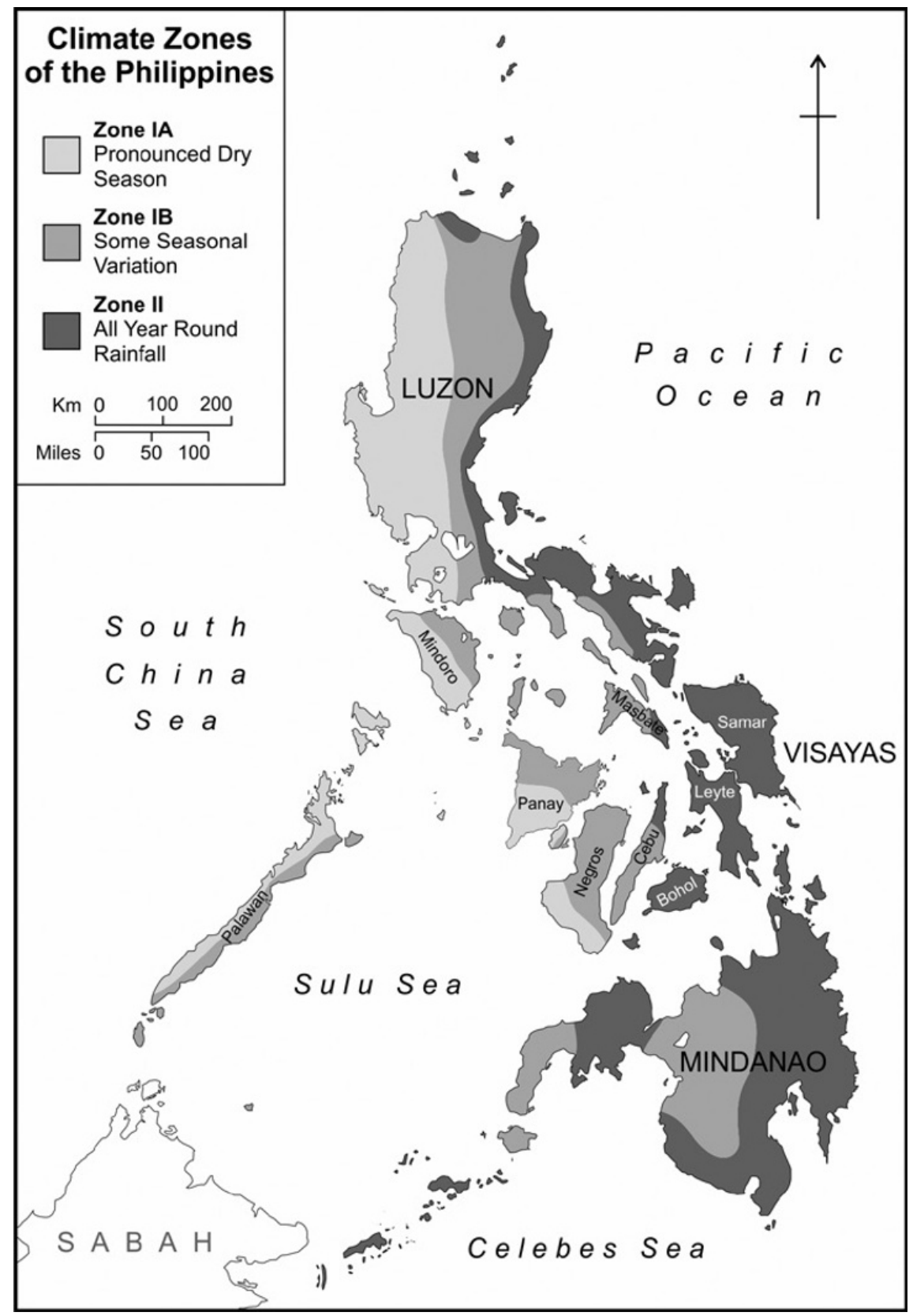

FIGURE 2.1 
other region: lauan (Shorea negrosensis), apitong (Dipterocarpus grandiflorus) and guijo (Shorea guiso) develop best in the east, while yacal (Shorea laevis), narra (Pterocarpus indicus) and molave (Vitex parviflora Juss.) grow best where there is a dry period. Grasslands are also more common in areas with a prolonged dry season. The principal effect of the wind upon vegetation depends on whether it is moisture-bearing or not (Matthews 1914:3-5).

Soil and subsoil are also important to the physical characteristics of the forest and to the distribution of species. Soil affords anchorage for trees and also constitutes the reservoir from which they derive water, nitrogen and other minerals. Tropical broad-leaved trees require tremendous amounts of water and hence forests are confined to regions with adequate rainfall. Just as important as water is soil depth; in general 1.5 meters is a sufficient depth for almost any tree. If the soil is deep and moisture-retentive, species that require high moisture may be able to exist in localities of relatively low rainfall. Conversely, trees that usually require less soil moisture may be unable to exist in regions of high rainfall if the soil is sandy or shallow. All species of tropical trees grow better in soil which is minimally deep, porous, moist, warm, and rich in humus (Matthews 1914:9-14).

As a result of the distinct precipitation shadow between the western and the eastern halves of the archipelago and differences in soil depth and moisture, the forests of the Philippines are quite varied in their composition. Six types of forests have been commonly identified. Dipterocarpaceae are generally large trees, reaching heights up to 50 metres and with diameters of 100-150 centimetres. They are mainly evergreens and found on nearly all terrains up to altitudes of 800 meters. The molave forest, on the other hand, is composed of non-dipterocarp hardwoods such as molave and narra. Such species form more open landscapes where the dominant trees are less abundant and set further apart, are short-boled and irregular in form, and have wide-spreading crowns. Their timber is much sought after because of its strength and durability. Other forest types are more localised: mangrove on the mud flats at the mouth of rivers and along the shoreline, beach forests in coastal areas, pine forests in the upland plateaus of northern and central Luzon, and mossy-forests in the high mountain regions (Whitford 1911:17-32). However, it is not altogether clear whether the forests have always existed in quite such proportions and other forest types might have been more plentiful in the past (Whitford 1911:26-31).

Gifford Pinchot, who visited the island in 1902, provides a valuable record of how the forest looked before large-scale logging. He noted how the forest came right down to the water's edge, even overhanging the high-water mark. ${ }^{2}$ The

2 LC, Pinchot Papers, box 640, 'XII Philippines':12, 16, 26, 25. 
trees were of an extraordinary size, many with diameters in excess of three feet but he was too unfamiliar with the species to get any idea of their distribution. ${ }^{3}$ There was, however, a general pattern to its appearance: Trees were shorter, smaller in diameter and 'less valuable' at the water's edge than they were

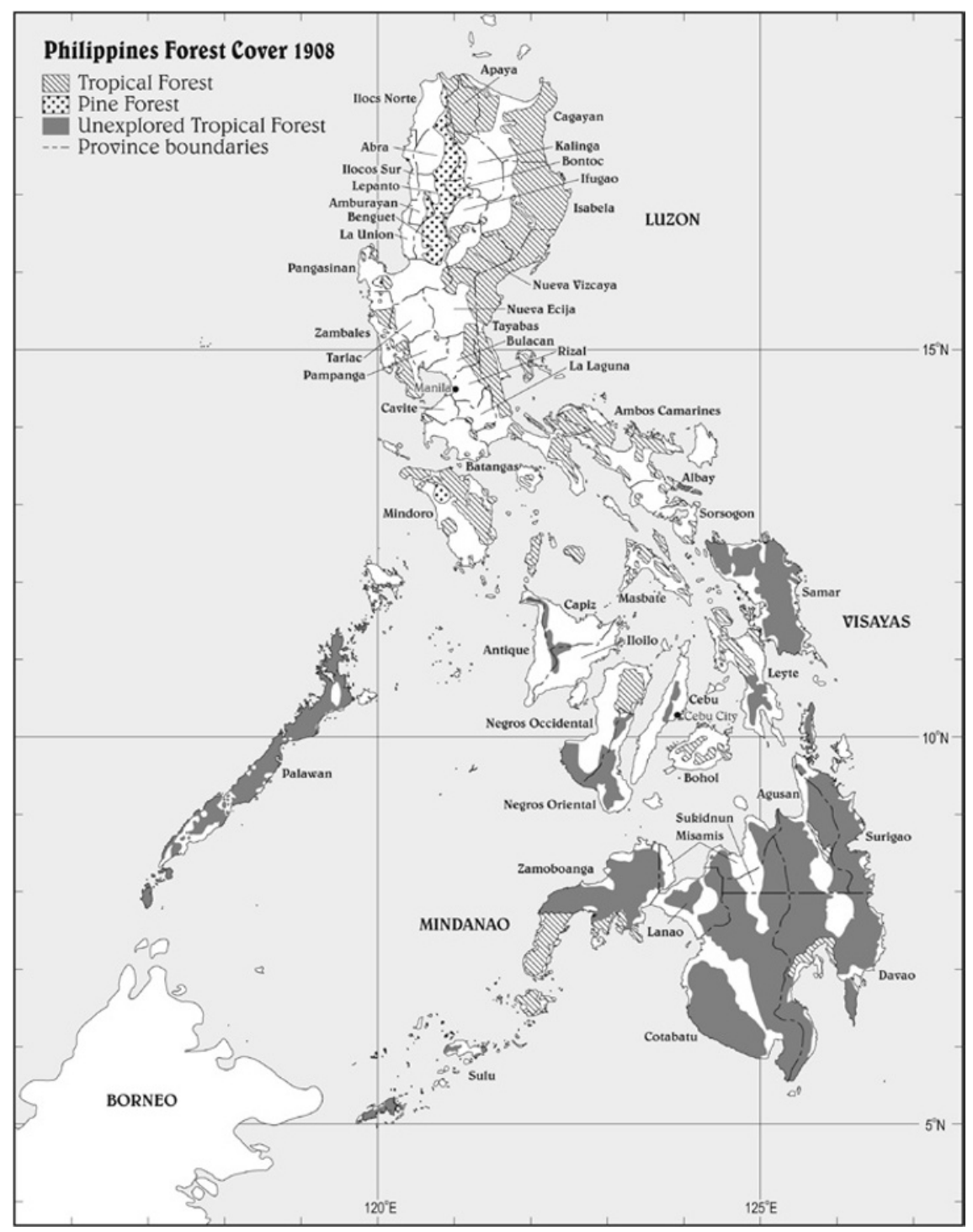

FIGURE 2.2

3 LC, Pinchot Papers, box 640, 'Philippine Islands'. 
farther inland. The finest timber with the best logs was always to be found on the steepest slopes but the forest began to diminish again the higher one climbed. ${ }^{4}$

\section{Fire and the Forest}

These forests, however, were not the work of climate and soil alone. Fire, too, shaped the forest, though the tropical vegetation was difficult to ignite and fire was not easily maintained in the moist, shaded environment under the dense tropical canopy. In those areas of the archipelago without a distinct dry season, the rapid onset of decomposition and the relentless activity of insects meant that there was little forest litter to sustain even a deliberately lit fire. Even in those areas that experienced a dry season, it was difficult for fire to spread. Only under exceptional circumstances was the forest rendered naturally vulnerable to fire. If, for instance, the dry season was unusually hot, then fire might spread from grassland to forest (Fuller and Murphy 2006). Typhoons also damaged trees, leaving the forest more susceptible to fire (Fischer 1929:35).

While fire may precede human activity in the forest, it invariably always accompanies it. Most fires were started by indigenous farmers practicing swidden or slash-and-burn agriculture (locally called kaingin). This 'indigenous' fire was an integral aspect of forest agriculture and always shared certain characteristics such as the use of fire in preparing the land, the shifting of crops from one field to another, and the abandonment of a field after one or two seasons (Conklin 1957).

Fire had a good deal to do with the type of vegetation which came to cover those areas abandoned by swidden farmers. Where clearings remained in cultivation for more than one season, little volunteer reproduction occurred and the soil became dry and baked, a condition favouring the colonization of the site by cogon (Imperata cylindrica), a tall perennial grass that grows widely in tropical regions (Report of the Chief 1906:278). By 1914, it was estimated that almost half the archipelago, some 48,ooo square miles was covered in grasslands (Matthews 1914:66). Grassland fires are frequent in those areas of the archipelago that experience a dry season (Matthews 1914:67). In the mountains, too, fire was frequent and fashioned a very particular vegetative regime (Fischer 1927:22, 1928:21). Upland peoples were pastoralists who regularly burned over the grass between the pines (Bryant 1907:9).

By the early nineteenth century, three distinct types of landscapes predominated over most of the Philippines: cultivated areas, open or semi-open

4 LC, Pinchot papers, box 640, 1902: file 9: 'Lecture on forests ... second half'. 
grasslands, and forest. The relative proportion of these areas varied according to physical features, soil quality, and the density of human population (Matthews 1914:67). As a general rule, agricultural lands occupied the fertile river valleys and adjacent slopes, grasslands spread over the rocky or steep slopes, and forests covered the mountains. While some fires were due to carelessness, most were deliberately lit by hunters eager to attract game (Report of the Chief 1906:278; Matthews 1914:4). The intense heat of these fires killed off surviving stumps as well as any seedlings, causing the tree line to slowly recede over time (Matthews 1914:67).

Europeans changed fire regimes, both intentionally and unintentionally. On the one hand, fire was the inadvertent consequence of the new steam-powered machinery used in commercial logging at the beginning of the twentieth century (Fischer 1923:38). Fires were more frequent during the dry season and especially in areas that had been logged (Forest District 1905:27). On the other hand, fires might be intentionally set to clear the ground before logs were skidded to a landing. Uncontrolled fire in logged over areas destroyed all forest growth. George Ahern (1913:11), first chief of the Philippine Island Bureau of Forestry, noted how: 'Even under most favourable conditions following logging operations the young seedlings have difficulty in withstanding the strong isolation to which they are exposed, but after such a destructive fire conditions are rendered altogether hopeless'. Fires in logged-over sites were frequent events by 1930 , and they were apparently 'becoming more and more of a problem'. Sometimes, too, fires were deliberately lit by forestry officials 'to clear up old caiñgins' or as a preventative measure before the start of the fire season (Forest District 1905:31; Fischer 1925:15). Europeans also shaped the forest: they abetted the spread of fire to locales where it had rarely been seen before, and, by clear cutting burnt over areas, encouraged the spread of grasslands.

\section{Anay: Shepherds of the Trees}

The termite or 'white ant' is integral to the very fabric of the forest. Known generically as anay in the Philippines, more than 1,500 different species are distributed throughout the Tropics. In tropical forests, anay remove ground litter and enrich the soil by working leaf-matter deeper into it. Most species only attack dead plant material but a few are serious pests to living trees (Dammerman 1929:26-27). In the Philippines, there are 54 species of termites. The most common species are the mound-building termite (Macrotermes gilvus) that constructs extensive systems of covered passages to attack dead wood including structural woodwork. The most destructive, however, is the 
Philippine milk termite (Coptotermes vastator). Other common species include the Los Baños termite (Microcerotermes losbanosenses) that attacks waste lumber and woodwork such as roof joists and rafters, and the Luzon point-headed termite (Nasutitermus luzonicus) that prefers to construct nests on tree trunks. Altogether these and other species are widely distributed, cause significant structural damage to buildings, and are considered serious pests (Acda 2004).

In the past, anay were the real masters of the shade beneath the forest canopy: They shaped the distribution of species growing in forests by influencing which trees people were willing to harvest. Of the hundreds of tree species to be found in the Philippine forest, only 30 to 40 were regularly felled. Over hundreds of years, the effect of felling only a few tree species was the 'complete exhaustion in certain provinces of the best kind of timber. 5 Trees that anay did not eat were the species mainly used by indigenous people. ${ }^{6}$ After the Spanish colonized the islands in 1565 , white ants continued to influence which tree species were logged. There was an increasing demand for hardwoods resistant to anay for use in the construction of new urban centres and upland fortifications. As Gifford Pinchot noted in 1903:

You find the ants everywhere, in the towns and out of them, and you find also that they have controlled the whole process of lumbering in the Islands until now, and the reason why the cut-over land is in its present condition in the Philippines, the reason why certain species are getting scarce in certain places, are almost entirely due to the fact that their timbers resist the white ant. What does not resist the white ant has been let alone. ${ }^{7}$

Similar sentiments had been expressed 26 years earlier by Spanish officials who were aware of the situation and appreciated that in Tayabas and other localities of this archipelago woods such as mangachapuy, betis, banaba and others of the most sought after species ... are already very scarce. ${ }^{8}$

Accessible stands of such timber were increasingly hard to find and mature, seed-bearing trees became exceedingly rare. This culling of the largest trees led to a form of genetic erosion, diminishing the contribution of a particular

5 LC, Pinchot papers, box 640, 1902: file 9: 'Lecture on forests; box 640, 1902: file 10: 'Lecture on forests ... second half', 'Lecture on forests ... first half'.

6 LC, Pinchot papers, box 640, 1902: file 10: 'Lecture on forests ... first half'.

7 LC, Pinchot papers, box 640, 1902: file 9: 'Lecture on forests; box 640, 1902: file 10: 'Lecture on forests ... second half', 'Lecture on forests ... first half'.

8 PNA, Ministerio de Ultramar ... Islands, 7 August 1877. 
species to the general biomass, and to the attenuation of remaining stands with consequences for the fauna and flora dependent upon them. Pressure on resistant tree species only diminished after 1910 when extensive field trials at the newly established timber testing laboratory at Los Baños discovered that creosote was an effective treatment against white ant. Subsequently, loggers harvested a larger number of timber species for construction purposes. ${ }^{9}$

In addition to white ants, other animals have also shaped forest cover. Cattle, sheep and horses have not so much led to forest destruction as hindered its regrowth. Domestic cattle were never numerous in the Philippines until the late nineteenth century and sheep were confined to upland areas (Edgerton 1982:375). The horse, too, was not native to the Philippines. First brought from New Spain and subsequently imported in much greater numbers from China and Japan, horses were successfully bred on 'great stock farms' in the seventeenth and eighteenth centuries (Bankoff 2001). Unlike cattle, horses played a significant role in the economic life of the wider society and horse-ownership among indigenous peoples was widespread by 1800 . For most of the year, however, these horses were moved to communal pastures in the uplands where they were left to scavenge for whatever they could find to eat. In this way, the horse was an unwitting agent hindering forest regeneration and turning cleared or logged areas into grasslands.

\section{State and Forest}

Making a division between non-human and human agents is somewhat arbitrary in deep forestry: It is often the symbiotic relationship between the nonhuman and human that proved to have such an important impact on the shape of the forest. Human actions in the Philippines undoubtedly had unforeseen results on the forest when coupled with the forces of the natural world, extending the reach of fire, bestowing on white ant the power to determine which species were cut or, as in the case of horses, hindering regrowth. All of which changed the composition of the forest beyond recognition. However, this human impact evolved in relation to the wider historical context, as a result of changes in demand for timber products and, ultimately, as the composition of the forest itself changed over time. In particular, the formation of the state in the mid-sixteenth century and the commercialization of forestry beginning in the mid- to late-nineteenth century were decisive turning points in the forest history of the Philippines.

9 NARA, General records of the Bureau of Insular Affairs, box 768, file 11896 . 
Not all timber has the same qualities and some are more conducive to human purposes than others. Certain species, therefore, have been felled more often than others. Trees or timber products were used among other purposes for housing, transportation, furniture, utensils, writing, medicine, as a source of heat and even as clothing. The tools of agriculture were primarily wooden as were largely the weapons of war. All this wood initially came from the forest so that the history of the forest is largely commensurate with the modern history of the societies that lived in and about it.

Little is known about the precise impact of pre-colonial societies on the environment. While no hydraulic states emerged in the archipelago to rival those found elsewhere in Southeast Asia, Metal Age chiefdoms existed and were able to expand quite rapidly with the advent of a foreign trade in Chinese porcelain after the tenth century. The added wealth this trade provided even created the conditions whereby several larger scale, inter-regional polities were able to develop at Manila, Cebu, Sulu, and Magindanao. Chiefly-power rested on engaging in alliance-building exchanges through attracting foreign luxury goods and augmenting the available labour supply by intensive maritime raiding. Raiding, in turn, prompted the increased construction of coastal fortifications, an expansion of metal weapon production, the adoption of foreign military technology, and the emergence of a specialized warrior class - all of which required wood (Junker 1999).

Warfare was a highly developed aspect of daily life in the pre-Hispanic Philippines and most of these weapons were made, at least in part, from wood (W. Scott 1994:147-151). Many Filipinos spent much of their time on water, and many military engagements also took place at sea. In these circumstances, the construction of warships was a highly developed aspect of military technology. These karakoras were sleek, double-ended vessels. They mounted a square sail and had double-outriggers on which paddlers provided speed in battle. They were light, flexible, extremely manoeuvrable and perfectly suited to the maritime conditions in which they operated. They were also fighting machine par excellence as Europeans later learnt to their discomfort. Karakoras reached bursts of speed of between twelve to fifteen knots in contrast to the five or six knots that a European galleon made (W. Scott 1981:5-10). As one Spanish observer ruefully noted in 1667 , "Their ships sail like birds, while ours are like lead in comparison' (Combes 1897:70-71).

The preferred wood used in the construction of karakoras was molave because of its strength. The prevalence of these crafts and the amount of wood felled for their construction is difficult to gauge. However, the Maguindanaos of Mindanao were able to muster a war fleet of a hundred such vessels to raid the Visayas in 1602, and Rajah Bongsu of Jolo apparently set out for southern 
Luzon in 1627 with a fleet that carried 2,00o fighting men (Corpuz 1989:141143). However, despite the fact that warfare was endemic in these pre- or protostate societies, the environmental effect on the forest was likely to have been localized and limited given the weaponry available and the low population density (Junker 1999:62).

The first large-scale, permanent revolution in land-use is usually associated with the development of a core region and the emergence of a state system in the Philippines after 1565 . On the one hand, this is a narrative about the construction of urban and municipal centres as sites of administration or evangelization. On the other hand, it is about the development of an early agricultural market and the introduction of new crops from the Americas. The erection and maintenance of this state so far from Europe also required defence. The subsequent construction of ships and forts intensified the demand for timber. However, simply equating state formation with deforestation is too crude an analysis. Not all wood serves human purposes equally well at any given time: particular woods were selected for specific purposes and felled regularly, while others were viewed as largely worthless and left largely alone (Boomgaard 1988:58-87).

In the Philippines, the cities and towns that are so characteristic of Spanish colonialism the world over were mainly built from woods. Even the capital, Manila, founded in 1571, was initially a collection of wooden structures (Morga 1903-1909:136-143). The indigenous house, the bahay-kubo, was primarily constructed of bamboo (Bambusa blumeana Schultes. f.), roofed with nipa palm (Nipa fruticans Wurmb.), and lashed together with rattan (Calamus maximus Blanco) (Alarcón 1991:23-77). They were raised on hardwood poles known as haligues, generally made of molave because of their termite-resistant qualities (W. Scott 1994:57-62). Spaniards continued to use the same materials, adapting them to the architectural forms of churches and other public buildings (Gentil 1903-1909:207).

Defence, too, required a constant source of newly-cut timber. The colony needed to defend against Dutch fleets and Moro (Muslim) raiders as the Spanish presence dragged the archipelago into a wider arena of conflict and religious antagonism (Warren 1985). The aim of the Dutch East Indies Company (VOC) was to hinder trade by blockading Manila, intercept the bullion-loaded Acapulco galleons and thwart Spanish attempts to establish a permanent presence in the Spice Islands (Muijzenberg 2000:12-15). War in the South was aggravated by Spanish attempts to subjugate the Muslim polities. Hostilities took the form of Moro raids and Spanish retaliatory expeditions that persisted into the nineteenth century (Corpuz 1989:135-158). What the Spaniards needed to defend their new possessions in the East were ships. Mindful of the need for suitable wood, early accounts of the islands were quick to appreciate their 
potential for shipbuilding (Mirandola 1903-1908:225; Sande 1903-1909:59). Not only was there an 'abundance of wood for all kinds of vessels' but Filipinos proved to be 'very skillful in making ships and fragatas' (Vera 1903-1909:206). By 1616, six out of the seven galleons stationed at Manila had been built in the islands (Pineda 1903-1909:180). These vessels also continually required regular refurbishing or replacement (Pineda 1903-1909:171-173).

How much timber was consumed over the decades is difficult to estimate. Some idea of the scale of the whole enterprise can be gleaned from the labour that was levied to meet these demands. As part of the corvée requirement indigenous people rendered the colonial state, municipalities had to provide people to work in the shipyards or cut timber (Cushner 1971:117-126). So great was the amount of wood required that it caused revolts, most notably in 1614 and 1649 (Corpuz 1989:124-128). Certain species of tree near shipyards were felled and their timbers used in shipbuilding and repair. Molave and other valuable hardwoods soon became increasingly difficult to find. Already by 1621, Hernando de los Rios Coronel commented on how difficult it was to 'find the necessary timbers of the forest' (Coronel 1903-1909:203).

The threat, however, was not only external. Spanish control over some parts of the archipelago remained tenuous right into the nineteenth century. Especially in the Cordilleras of central Luzon, frontier communities evolved based on forts and military garrisons, a presidio (fort) society. Subject to missionary contact and irregular military expeditions since the sixteenth century, Governor-generals did not try to impose colonial order on upland peoples until the nineteenth century (W. Scott 1974:3-4). Even then, the Spanish presence remained primarily a military occupation based on garrison towns and forts, dependent on lowland sources for provisions and guns to enforce compliance (W. Scott 1974:296). Like the naval craft that defended the colony from the sea, the forts that straddled the highlands were also constructed of timber and were often elaborate affairs, palisades with parapets protected by moats, earthworks and outer stockades (W. Scott 1974:272-273). Given the number of presidios situated at strategic locations all over the Cordillera as well as in other parts of the archipelago, the amount of timber required in their construction and maintenance was considerable. Again the use of valuable hardwoods further contributed to the reproductive erosion of certain species, reducing the genetic diversity of the forest by leaving only less desirable individuals to produce seed. A report on the state of the forest in 1877 blamed the unregulated activities of woodcutters for a scarcity of 'valuable trees of large dimensions', and the preponderance of 'juvenile ones' which had led to the 'impoverishment' of the forest. ${ }^{10}$ 
All this amounted to a very changed landscape in many parts of the archipelago by the late nineteenth century. The extent of deforestation is difficult to reconstruct. A detailed provincial breakdown of forest cover was published by the Spanish forestry department in 1875 . According to this estimate, $70 \%$ of the islands was still forested after more than 300 years of Spanish rule. This percentage, however, is based on the total land area of the present nation state and not on the territories under effective colonial administration. Until the early twentieth century, much of the largely untouched forests of Mindanao lay beyond the effective control of authorities in Manila. Subtracting the latter's some nine and a half million hectares from the approximate national total of 30 million hectares reveals the true extent of deforestation by the end of the nineteenth century. Using this formulation, about half the forest cover in the territory under Spanish control had already disappeared prior to the American era (Vidal y Soler 1875:40; Bankoff 2007c).

\section{The Commercialization of the Forest}

What fundamentally changed the nature of the human impact on the forests of the Philippines was the commercialization of the timber trade in the second half of the nineteenth century. While the volume of timber cut during the American colonial period increased markedly, especially after 1918, three-quarters of it still went to supply the domestic market just as it had under the previous regime. Historians have long argued that the Americans introduced scientific forestry, but an official forestry service was established in the Philippines in 1863, eighteen years before the United States established its Division of Forestry (Roth 1983; Tucker 1988). Forest regulations in the archipelago long preceded the establishment of a forestry service. The Recopilación de las Leyes de Indias had two objectives: protecting customary access to the forest and encouraging its conservation. Spaniards in the nineteenth century regarded the spirit of this legal corpus and its regard for indigenous rights as constituting 'the glory' of their dominion in the archipelago (Vidal y Soler 1875:59-6o, 81). Unfortunately, such laws were largely disregarded. Moreover, most new laws enacted during the first half of the nineteenth century were to encourage agricultural expansion usually at the expense of the forest (Vidal y Soler 1875:65, 67). It was the flagrant disregard for forest laws, the sheer scale of the destruction, the shortage of timber in many areas, and public criticism that persuaded the Spanish colonial administration to establish a forestry service in $1863 .{ }^{11}$

11 Vidal y Soler (1874:20); Jordana y Morera (1891:228); LC, Pinchot Papers, box 586, 'Regino Garcia':9. 
Other forces were at work in the forests by then, too, not least the emergence of a commercial market for wood and the perceived need to manage the remaining stands in a scientific manner. Certainly a timber market had emerged in the archipelago by mid-nineteenth century (Burzynski 2002:171-180). The stimulus for this market was the growth of Manila and to a lesser extent other urban centres (Foreman 1899:355). The rapid urbanization of the capital generated a strong demand for timber that soared in the aftermath of major disasters such as earthquakes (1863 and 1880) and fire (1870). Owners with substantial houses to repair needed timber; prices rose and local merchants seized the opportunity to make substantial profits (Bankoff 2012).

Along with the growing demand for timber and the increasing problems of supply was the realization that the forests of the Philippines had to be managed more systematically. The model that Spanish foresters had in mind was a programme of artificial reforestation (planting nursery-grown trees or seeds and saplings gathered in the wild) and selective logging that took account of the growth rate of each species (Vidal y Soler 1874:25). To implement such a programme, foresters first needed to conduct surveys to determine which areas were to be logged and which were to be kept as forest (Vidal y Soler 1874:126). Foresters in the Inspección general de Montes may have been trained in German and French silvicultural principles but they adjusted European forestry to meet the particular conditions of tropical forests. The service began modestly in 1863 and grew to be a sizable agency (Nano 1953:13). The primary legislation the service operated under was the provisional forestry regulations of 8 February 1873 that Ramón Jordana y Morera, author of the most definitive account of forestry in the Spanish Philippines, considered expressed the most advanced scientific principles of the time. However, even he had to admit that they had been formulated with little knowledge on how best to achieve these aims and [in ignorance] of the customs and necessities of the inhabitants' (Jordana y Morera 1891:241-242). The forestry service continued to operate right up until the end of the Spanish colonial period though its effectiveness was hampered by a gradual reduction in the number of staff after 1881 . Unfortunately, its historical legacy has suffered much from the fire of 1897 that destroyed its extensive library, forest maps, natural history collection, and the entire archives. ${ }^{12}$

There does not appear to have been any appreciable loss of forest cover due to campaigning during the American occupation of the archipelago between 1898 and 1907. Nevertheless, the new U.s. administration realized the extent of deforestation in the more populated areas of the archipelago (Ahern 1901:11).

12 LC, Pinchot Papers, box 586, 'Regino Garcia': 5-6. 
Officials assessed this damage, however, more in terms of lost revenue and were struck by the amount of primary forest that still remained. 'The Philippine forests', wrote Worcester (1914:847), was 'like money in the bank'. By the beginning of the twentieth century, Americans were fast exhausting even their own prolific domestic timber reserves; foresters talked with urgency of an impending 'timber famine' and looked upon their new colonial possessions as a source of timber (Williams 2003:386-395). Worcester extolled the myriad uses for the different types of timber and non-timber products and a flow of publications detailing knowledge about the forest and the commercial usefulness of Philippine timber was a hallmark of the early decades of the American era (Miller 1911:97-111; Schneider 1916).

The period from 1898 to World War Two witnessed an enormous expansion of commercial logging around the archipelago with exports to markets in the USA, Japan, China and Europe (Schneider 1916:11). To meet this demand, operations were modernized with logging engines and railways largely replacing axes and carabaos (Collins 1901:82). Total annual lumber production rose from 94,00o to 2,500,000 cubic metres between 1901 and 1940. In particular, the volume of timber cut from lesser quality dipterocarp hardwoods (such as apitong, lauan and tangile) rose by over a $1,000 \%{ }^{13} \mathrm{~A}$ moving timber frontier embraced the whole archipelago with the inclusion of extensive logging operations on Mindanao. A displaced and rapidly expanding population, moreover, sought new land to cultivate that was literally hacked out of the forest, with or without official consent. This encroachment only accelerated after the establishment of internal self-rule in 1935 (Severo et al. 1962:3). Again, the overall figures on forest cover do not properly reflect the magnitude of this loss. The inclusion of Mindanao into the colonial state in 1898 , an island 'almost entirely covered in timber', effectively increased the extent of forest cover in the archipelago by a third. Yet by 1932 forest covered only $57 \%$ of the total land area, a fall of a further $9 \%$ since 1903 (Ahern 1901:11). The Great Depression of the early 1930s proved only a temporary respite.

The need for both timber and food intensified with the Japanese invasion and the harnessing of the archipelago's forests for wartime purposes. After a systematic bombing of Philippine defences, Japanese troops landed on 10 December, 1941 at several points on Luzon and rapidly overran the less wellequipped and much smaller American and Filipino forces. The Japanese were determined to make full use of the archipelago's forest resources not only the wood but also non-timber products such as rattan, resins, gums, tannin, oils and medicinal plants. However, timber production during the occupation was only a fraction of its pre-war level (Sulit 1947:35). Many factors explain this

13 Fischer (1925:64, 1937: 87-88, 238-239); Tamesis (1948: 320). 
poor performance: wartime damage to mills, a shortage of draught animals, unrealistically low fixed timber prices, and the uncooperativeness of Filipinos, as well as widespread sabotage by guerrilla fighters (Sulit 1947:38-39). Despite plummeting production figures, however, the damage inflicted on the archipelago's forests during the occupation was substantial (Agoncillo 2001:607-635). Food shortages led to an unregulated explosion of slash-and-burn agriculture and to the clearance of much woodland (Severo et al. 1962:4). The Japanese military's demand for timber resulted in the extensive destruction of forest habitats including trees in national parks and forest reserves (Sulit 1947:40-41). Moreover, intense fighting occurred in many forested areas, first in early 1942 and again as a result of the scorched earth policy practiced by the Japanese Army in the months following the American landing in October 1944. The sheer scale of the destruction and the random indiscriminateness of the damage inflicted on the forest separate the Japanese occupation from all previous wartime experiences in the Philippines.

In the decades following World War Two, the wholesale commercial exploitation of the forest began in earnest, especially during the presidency of Ferdinand Marcos (1965-1986) (Broad and Cavanagh 1993:39-55). These years were characterized by cronyism, corruption, and corporate logging as the archipelago's forests were plundered on an unsustainable basis (Vitug 1993). Forest cover declined from $50 \%$ of land area to a little over $22 \%$ between 1950 and 1987 (Kummer 1992:56-57). The rapid decline in forest cover was not due solely to intensive logging (both legal and illegal) but also resulted in part from an expanding agricultural frontier to accommodate the archipelago's rising number of people. Population increased from 19.3 million to over 48 million between 1948 and 1980 (Kummer 1992:77). The decades following 1945 also saw the Philippines emerge as the major producer of tropical hardwoods in Southeast Asia for international markets. National log exports peaked at a high of 8.7 million cubic meters in 1969 before falling back to $5 \%$ of total exports by 1987 (Top 1998:64).

After the restoration of constitutional government in 1986, more progressive forest policies were introduced that included people-oriented social forestry programs. Provincial and local logging bans were instituted and forest reserves created. Reforestation projects and spontaneous tree-planting contributed to a rise of 0.7 million hectares in forest cover between 1988 and 2003. Since 1995, too, there has been greater official understanding that conservation and reforestation projects can only succeed with the direct involvement and participation of forest users. Community-based forestry management agreements that recognize local communities as forest managers are now acknowledged national strategy and, by 2006 , over 6,000,00o hectares of forest lands were under some form of community forest management (Lasco and Pulhin 2006:48). Still, it may 
be rather premature to conclude that this trend represents a new phase in the relationship of humans to the forest. Indeed, such statistics often lack robustness and illegal logging and forest clearance continue apace in many areas, often cloaked in the rhetoric of community empowerment and poverty alleviation (Ploeg et al. 2011). By the end of the twentieth century, too, the Philippines had become a net importer of tropical hardwoods.

\section{Conclusion: Deep Forestry and the Longue Durée}

Adopting a 'deep forestry' approach may not really allow one to 'think more like a forest' but it does help reveal the true dynamics that govern the nature, composition and extent of the forest in the Philippines over the longue durée. In the first place, deep forestry offers a more inclusive understanding of the archipelago's woodlands: how they changed over time, who or what were the agents that precipitated such modifications, and what have been the consequences of their actions. Climate, soil, fire and animals were significant factors not only in determining the nature and composition of the forest but also in influencing human decision-making. As a result, any historiography of the forest needs to encompass an extended timespan that includes all these actors in its narrative. Seeing the forest as more than simply its constituent trees highlights its real value not only as a resource but as an important stabilizing element in the environment.

Taking a more biocentric approach shows how forest history is more than a mere chronicle of human actions. The sheer scale of forest clearance since 1946 has dwarfed most other considerations, but people have always acted with and within a forest ecosystem. The full impact of fire and white ant has been synergistic with human agency, while the soil and even the climate are nowadays also the product of a close interaction with people. In particular, climate change is set to become a major determinant of future agricultural yields as well as the health of the archipelago's remaining forests. Forest historiography needs to reflect these complex and dynamic processes. Finally, thinking more like a forest is a reminder to all that the forest has always acted as a community's first line of defence against the vicissitudes of climate and the extremes of seismicity. The Philippines are one of the most disaster-prone nations on earth with an average of 20 typhoons a year and an earthquake of varying magnitude occurring somewhere in the islands every day (Bankoff 2003). A deep forestry approach appreciates this contribution and the significant part the forest plays in mitigating the potentially destructive power of natural forces in an increasingly less predictable world. 